\title{
Women's rights are central to improving respiratory health in childhood and must be urgently addressed
}

Ian Sinha ${ }^{1}$ and Susanna McColley ${ }^{2}$

${ }^{1}$ Alder Hey Children's Hospital

${ }^{2}$ Ann and Robert H Lurie Children's Hospital of Chicago

March 25, 2021

\section{Hosted file}

SINHA COMMENTARY womens rights final sam.pdf available at https://authorea.com/users/402631/ articles/515281-women-s-rights-are-central-to-improving-respiratory-health-in-childhoodand-must-be-urgently-addressed 